Vol. 11 (2002): 329-342.

\title{
Review
}

\section{The soil quality concept and its importance in the study of Finnish arable soils}

\author{
Ansa Palojärvi and Visa Nuutinen \\ MTT Agrifood Research Finland, Environmental Research, Soils and Environment, FIN-31600 Jokioinen, Finland, \\ e-mail: ansa.palojarvi@mtt.fi
}

\begin{abstract}
Arable soil is a functional unit whose condition is vital to crop production, but also to ecosystems at large owing to the significant role of soil in global nutrient cycles and balances. The soil quality concept recognises the concern for the sustainability of current arable land use practices. It integrates soil chemical, physical and biological properties, and takes account of the interaction of soil with water and air. This paper reviews the soil quality concept and its applications and discusses the importance of the concept for the assessment of Finnish arable soils. Many aspects of the chemical quality of arable soil are already well known in Finland. In contrast, follow-up of the physical and biological soil components, which are increasingly seen as important features of soil quality, is rudimentary. For monitoring of the soil quality at different scales - field, regional, national and global a suitable set of indicators needs to be identified. In this paper particular attention is paid to the potential importance and usefulness of selected biological indicators. It is clear that more basic research is needed to provide scientists and advisors with a solid basis for transmitting reliable information on soil quality. While the soil quality concept has been justifiably criticised, it has clear merits in the integrated handling of the soil entity and in highlighting the environmental aspects of arable soil quality.
\end{abstract}

Key words: soil quality, sustainability, indicators, monitoring, soil biology, soil microbiology, soil fauna, earthworms

\section{Soil as a functional unit}

Soil is a dynamic, living resource whose condition is vital to both the production of food and fibre and to global balance and ecosystem function (Doran et al. 1996). Blum and Santelises (1994) describe a concept of sustainability and soil resilience based on six main soil functions:
Ecological functions:

(i) biomass production (food, fibre and energy),

(ii) the soil as a reactor which filters, buffers, and transforms matter to protect the environment, groundwater and the food chain from pollution,

(iii) soil as a biological habitat and genetic re- 


\section{Palojärvi, A. \& Nuutinen, V. Soil quality concept}

serve for many plants, animals, and other organisms.

Functions linked to human activity:

(i) the soil as a physical medium, serving as a spatial base for buildings and transport,

(ii) soil as a source of raw materials supplying water, clay, minerals etc.,

(iii) soil as part of our cultural heritage (archeological treasures etc.).

Soil serves as a medium for plant growth by providing physical support, water, essential nutrients and oxygen for roots. Soil plays a key role in completing the cycling of major elements required by biological systems (e.g. carbon (C), nitrogen $(\mathrm{N})$, phosphorus $(\mathrm{P})$ and sulphur $(\mathrm{S})$ ), in decomposing organic wastes and in detoxifying certain hazardous compounds through microbiological and chemical processes. Ability of a soil to store and transport water is a major factor controlling water availability to plants and the transport of environmental pollutants to surface and ground water.

\section{Global and local problems in agricultural soils}

Development of modern agricultural management practices, such as extensive soil cultivation, monoculture production and greater reliance on chemical fertilisers and pesticides, has resulted in dramatic increases in crop yields. Undesirable side-effects have been increased organic matter loss, soil compaction and erosion, and surface and ground water contamination. These have contributed to the situation documented by the Unite Nations (UN) Environment Program on "Global assessment of soil degradation" that almost $40 \%$ of agricultural land has been adversely affected by human-induced soil degradation (Oldeman 1994).

Sustainable use of agricultural soils is thus gaining more and more attention. Since many of the soil's physical, chemical and biological properties are a function of soil organic matter, the downward trend in the humus content of arable soils is of great concern. The present threats of global climate change and ozone depletion, through elevated levels of certain atmospheric gases and altered hydrological cycles, necessitate a better understanding of the influence of land management on soil processes (Doran and Safley 1997). Management systems need to be further improved and developed to balance the need and priorities for food production with those for a safe and clean environment.

Nutrient leaching from fields and eutrophication of waterways have been of particular interest in Finland (Valpasvuo-Jaatinen et al. 1997). Kylä-Setälä and Assmuth (1996) concluded that compaction and erosion of arable land are locally important problems, even though comprehensive national surveys are lacking. They considered an assessment of the biological state of Finnish arable soils to be difficult due to the lack of monitoring programmes.

\section{Soil quality concept}

The need for a methodology for characterisation of soil quality is being increasingly recognised. Earlier, soil quality was taken as a synonym for the capacity of soil to produce yield, that is, as a synonym for soil fertility. In recent years soil quality is being seen to involve more than inorganic chemical soil tests and crop yield (Harris and Bezdicek 1994). Problems related to soil quality and function, other than nutrient deficiency, include poor water infiltration, crusting, erosion and poor biological activity, together resulting in poor nutrient cycling, reduced crop growth and soil degradation. Many of these problems are related to poor soil structure, which, in turn, is affected by biological activity (Ladd et al. 1996). The definition of soil fertility may not always be that clear (see e.g. Patzel et al. 2000), but the difference between soil fertility and qual- 
Vol. 11 (2002): 329-342.

ity is, that the soil quality concept is a broader term encompassing sustainability on ecosystem level.

\section{Soil quality and soil health}

The simplest definition of soil quality is "the capacity (of soil) to function" (Doran and Parkin 1994). An expanded version of the definition defines soil quality as "the capacity of a specific kind of soil to function, within natural or managed ecosystem boundaries, to sustain plant and animal productivity, maintain or enhance water and air quality, and support human health and habitation" (Karlen et al. 1997).

In slightly different words, Larson and Pierce (1994) defines the quality of soil by the ability of soil to perform specific functions:

(i) provide a medium for plant growth and biological activity,

(ii) regulate and partition water flow and storage in the environment

(iii) serve as an environmental buffer in the formation and destruction of environmentally hazardous compounds.

Soil quality represents a composite of a soil's chemical, physical and biological properties (Doran and Safley 1997). The exact criteria for soil quality are based on the purpose of soil use.

The term soil health is often used as a synonym for soil quality, even though the descriptions of the terms may have slightly different emphasis. According to Doran and Safley (1997), soil health can be defined in its broadest sense as the ability of soil to perform or function according to its potential, and it changes over time due to human use and management or natural events. Soil health describes the soil as a living entity, and it comprises the inherent characteristics of soil.

\section{Measurement of soil quality}

For the use of soil quality assessment as a tool for evaluating sustainability and ecosystem re- sponse, it is essential to recognise that (i) spatial and temporal scales are critical, and (ii) soil quality depends on both inherent and dynamic properties and processes (Karlen et al. 2001). Inherent properties include the basic soil forming factors, such as parent material, climate, time, topography and vegetation. Dynamic characteristics result from the long- and short-term effects of management. A full array of biological, chemical and physical tests should be taken into account because of the holistic nature of soil quality.

Understanding of soil quality and the multiple interactions within its compartments requires research on soil properties and processes. This should include basic studies on the effects of different treatments and managements on soil, and should give insight into soil functions while serving as a means of assessment mean for selecting proper tools for soil quality monitoring.

Monitoring on field scale would enable farmers to identify problems at an early stage, and help them to decide what measures are needed to eliminate or alleviate the factor that is impairing soil function and limiting productivity. The ultimate goal is the most profitable and environmentally sound long-term management system for farms and fields as a whole (Sarrantonio et al. 1996). Monitoring on regional and national scales, in turn, would offer information to policy makers and administration, and enable modelling.

\section{Soil quality indicators}

Soil quality indicators refer to measurable soil attributes that influence the capacity of soil to perform crop production or environmental functions (Arshad and Martin 2002). Attributes that are most sensitive to management are the most desirable as indicators.

Doran and Safley (1997) listed several criteria for soil quality indicators. Indicators should:

(i) correlate well with ecosystem processes, 


\section{Palojärvi, A. \& Nuutinen, V. Soil quality concept}

(ii) integrate soil physical, chemical, and biological properties and processes and serve as basic inputs for estimation of soil properties or functions which are more difficult to measure directly,

(iii) be relatively easy to use under field conditions and be assessable by both specialists and producers,

(iv) be sensitive to variations in management and climate; the indicators should be sensitive enough to reflect the influence of management and climate on long-term changes in soil quality but not be so sensitive as to be influenced by short-term weather patterns,

(v) be components of existing soil data bases where possible.

Some researchers have proposed procedures for evaluating soil quality functions, depending upon the user goals and socio-economic concerns (Arshad and Martin 2002). The International Organization for Standardization (ISO) has published several standards for soil quality analysis, including some microbiological and faunal ones (Nortcliff 2002).

\section{Chemical and physical properties}

Chemical properties of soil have long been used as soil fertility indicators. The methodology is well established and standardised. The most important chemical properties are organic matter content, $\mathrm{pH}$, electrical conductivity and extractable $\mathrm{P}$, potassium $(\mathrm{K})$ and $\mathrm{N}$. All are essential contributors to crop growth and the welfare of soil organisms. The information on nutrient levels is in regular use by farmers to adjust fertiliser and liming regimes. The same information can be used for modelling and evaluating environmental risks in different scales.

Soil physical properties comprise attributes concerning the water regime and thus also the movement of nutrients in soil as well as the oxygen status of soil. These attributes also regu- late the ability of roots and organisms to penetrate and occupy the soil. Some soil physical measurements, like texture and bulk density, are in common use, but detailed information about soil porosity and aggregation is seldom gathered.

\section{Biological soil quality indicators}

The biological component of the soil consists of roots and organisms, including microbes and invertebrates. Biological systems are hierarchical, and that raises the question of the proper level of assessment when considering the use of bioindicators. Following Linden et al. (1994) and Stenberg (1999), three main levels of biological soil quality indicators can be distinguished: (i) organisms and populations (features of individuals, population parameters), (ii) communities (functional groups, potential rates of specific activities, trophic groups, diversity) and (iii) biological processes on ecosystem level (bioaccumulation, decomposition, soil structure modification).

There is growing evidence that soil biological parameters hold potential as early and sensitive indicators of soil ecological stress or restoration, reflecting impacts of soil management practices on soil function (Stenberg 1999). The application of soil biological components in soil quality follow-ups is very often hindered by the limited amount of background data. In the following, the most common biological soil quality indicators are reviewed and their applicability is evaluated.

\section{Microbiological properties}

Bacteria and fungi are the main groups of microbes in arable soils. Though small in size, they contribute to many important functions in soil. As pointed out by Stenberg (1999): (i) microbes have key functions in the degradation and recycling of organic matter and nutrients, (ii) they 
Vol. 11 (2002): 329-342.

Table 1. A selection of microbiological properties suggested as soil quality indicators.

Microbiological properties

Soil microbial biomass and numbers

Soil microbial activity

Soil microbial diversity and community structure

Plant-microorganism relationships
Microbial biomass $\mathrm{C}$ and $\mathrm{N}$

Direct counts

Soil respiration

$\mathrm{N}$-mineralisation

Nitrification

Thymidine and leucine incorporation

DNA profiles

Phospholipid fatty acid profiles

Community level physiological profiles

Enzyme-activity profiles

Suppressiveness

Mycorrhiza

$\mathrm{N}_{2}$-fixation respond promptly to changes in soil environments, and (iii) their activity in soil reflects the sum of all factors regulating the degradation and transformation of nutrients.

One of the main problems in the use of microbiological indicators for soil quality estimation is interpreting the results. Baseline and threshold values are not yet well established, and there is little information about the inherent spatial variability of microbial community structures and activities. Another difficulty is the rather large temporal fluctuation in microbial activity within a given area. This may be overcome by standardising the sampling techniques and timing, and by laboratory analysis of potential microbial activities.

A vast number of microbiological tests have been suggested as soil quality indicators (Table 1). Stenberg (1999) evaluated many of them in a review paper. Microbial biomass $(\mathrm{C}$ and $\mathrm{N})$, potentially mineralisable nitrogen and soil respiration are most often proposed as applicable biological soil quality indicators. Microbial biomass shows the total microbial catalytic potential and may act as an early warning for changes in soil organic matter. Potentially mineralisable $\mathrm{N}$ determines potential $\mathrm{N}$ supply and soil productivity. Soil respiration estimates the overall microbial activity.
The microbiology of Finnish arable soils is a relatively unexplored field, but recently studies on different management systems have been compiled (Palojärvi et al. 2002, Vestberg et al. 2002).

\section{Soil fauna}

The fauna of arable soils consists of a taxonomically and morphologically diverse assortment of animal species. Here the focus is on the species of the decomposer food web whose resource base is soil organic matter.

Soil fauna is commonly divided into three size categories. The division is useful as it captures the fundamental differences in the life style of animals, their position in the food web and their effects on soil functions. Grouping based on body width recognises three size classes: microfauna, mesofauna and combined macroand megafauna (Swift et al. 1979, Table 2). The size regimes correspond with Lavelle's (1997) functional hierarchy of soil animals, which comprises, respectively, micropredators, litter transformers and ecosystem engineers. Each functional group has its characteristic influences on soil processes. Many of the effects relate to important aspects of arable soil quality, most impor- 


\section{Palojärvi, A. \& Nuutinen, V. Soil quality concept}

Table 2. Division of soil fauna into size regimes and functional roles.

\begin{tabular}{|c|c|c|c|c|}
\hline \multirow[b]{2}{*}{$\begin{array}{l}\text { Size regime } \\
{\text { (body width })^{1}}^{1}\end{array}$} & \multirow[b]{2}{*}{ Main functional role ${ }^{2}$} & \multirow[b]{2}{*}{$\begin{array}{l}\text { Representative } \\
\text { group }(\mathrm{s})\end{array}$} & \multicolumn{2}{|l|}{ Influences in soil ${ }^{3}$} \\
\hline & & & Nutrient cycling & Soil structure \\
\hline $\begin{array}{l}\text { Microfauna } \\
(<0.1 \mathrm{~mm})\end{array}$ & Micropredators & Nematodes & $\begin{array}{l}\text { Regulate populations of } \\
\text { microbes, affect turnover } \\
\text { of nutrients }\end{array}$ & $\begin{array}{l}\text { May affect aggregate } \\
\text { structure via interaction } \\
\text { with microbes }\end{array}$ \\
\hline $\begin{array}{l}\text { Mesofauna } \\
(0.1-2 \mathrm{~mm})\end{array}$ & Litter transformers & $\begin{array}{l}\text { Enchytraeids, } \\
\text { Collembolans, } \\
\text { Mites }\end{array}$ & $\begin{array}{l}\text { Regulate populations of } \\
\text { microbes, affect turnover } \\
\text { of nutrients, fragment } \\
\text { residues of plants }\end{array}$ & $\begin{array}{l}\text { Produce organic faecal } \\
\text { pellets, create small } \\
\text { biopores, promote } \\
\text { formation of humus }\end{array}$ \\
\hline $\begin{array}{l}\text { Macro- and } \\
\text { megafauna } \\
(>2 \mathrm{~mm})\end{array}$ & Ecosystem engineers & Earthworms & $\begin{array}{l}\text { Fragment residues of plants, } \\
\text { stimulate activity of microbes }\end{array}$ & $\begin{array}{l}\text { Mix organic and mineral } \\
\text { particles, redistribute } \\
\text { organic matter and microbes, } \\
\text { produce organomineral } \\
\text { faecal pellets, create large } \\
\text { biopores, promote formation } \\
\text { of humus }\end{array}$ \\
\hline
\end{tabular}

${ }^{1}$ Swift et al. 1979, ${ }^{2}$ Lavelle 1997, ${ }^{3}$ modified from Hendrix et al. 1990

tantly decomposition, nutrient cycling and formation of soil structure (Table 2).

Not a single spadefull of Finnish arable soil has been comprehensively studied for its fauna, and knowledge of the distribution and abundance patterns of many field soil animals is scanty. In a recent farm soil survey the numbers of individuals per square metre were estimated at millions for nematodes, tens of thousands for mites, collembolans and enchytraeids and from a few individuals to nearly a hundred for earthworms (Palojärvi et al. 2002).

In any survey of faunal abundance in field soils, one must first decide what aspect of diversity to address. In his discussion of the relationship of soil biodiversity and ecosystem function, Bengtsson (1998) concluded that the study of functional groups and keystone species is a fruitful approach. We believe that the same approach would be useful for soil quality assessment.

Examination of soil quality literature and existing assessment schemes suggests that nematodes and earthworms are most often proposed or used as faunal indicators of arable soil quali- ty (e.g. Linden et al. 1994, Blair et al. 1996 and refs. in the Appendix). Earthworms are mentioned particularly often, evidently because of their keystone role in many soils and the relatively well documented effects of field management on earthworm populations (e.g. Lee 1985). In the Appendix, the evaluation of the applicability of a biological soil quality indicator is presented, using earthworms as an example.

\section{Minimum data set}

No single indicator is able to reflect the complex nature of soil. Several key indicators, with their critical limits (threshold values) that must be maintained for normal functioning of the soil, are required to monitor changes and determine trends in the improvement or deterioration of soil quality. A minimum number of indicators (minimum data set) need to be measured to evaluate the changes in soil quality resulting from various management systems. Larson and Pierce 
Vol. 11 (2002): 329-342.

Table 3. Proposed minimum data set of physical, chemical, and biological indicators for soil quality determinations (after Doran and Parkin 1994, Larson and Pierce 1994).

\begin{tabular}{lll}
\hline Indicators & Chemical & Biological \\
Physical & Soil organic matter & Microbial biomass C and N \\
Texture & $\mathrm{pH}$ & Potentially mineralisable N \\
Topsoil and rooting depth & Electrical conductivity & Soil respiration \\
Infiltration & Extractable N, P and K & \\
Soil bulk density & & \\
Water holding capacity & & \\
\hline
\end{tabular}

(1994) suggest a minimum data set consisting of several chemical, physical and biological indicators (Table 3). The selection must be adapted for different agro-ecological zones, and for use at regional, national and global levels (Arshad and Martin 2002).

\section{Soil quality follow-up in different scales}

Soil quality is evaluated mainly to provide farmers and advisors with a soil management instrument and to monitor the sustainability of arable land use (e.g. Doran and Parkin 1994). The different uses of soil quality relate to widely different spatial and temporal scales of measurement, which implies differences in the practical approaches adopted. Below, we provide a limited review of monitoring programs at international and national levels and give examples of onfarm assessment tools, paying particular attention to the use of biological variables in the assessment.

\section{International programmes}

Among the international follow-up programmes, the OECD's agri-environmental indicator scheme is well established and is being actively implemented (OECD 2001). Presumably due to the broad geographical scale of the programme, it addresses soil quality in a specific way: the two soil quality indicators chosen are the risks of wind and water erosion (Table 4). The European Union is currently developing its own agrienvironmental monitoring system (CEC 2001). Soil quality has been taken up in the planning but only sketchily. Mismatch between land use and soil capability is the sole "soil quality" indicator included, although soil pesticide contamination and erosion risk are mentioned as candidate indicators. The European Environmental Agency's (EEA) indicator system relates to all soils irrespective of land use and the system does not produce information relating to agricultural soils in particular.

The need to develop soil biodiversity indicators (SBIs) has been stressed within the OECD programme (OECD 2001). SBIs are regarded as promising indicators because they could summarise soil quality components which are otherwise difficult, expensive or time-consuming to measure. Soil microbiological and faunal (earthworms) features of soil communities are mentioned as candidate SBIs. Within the programme, two things are mentioned as major obstacles in the application of SBIs. First, no clear relationship has been established between soil organisms and arable soil quality (a point we would partially question). Secondly, and perhaps more importantly, many biological soil properties are sensitive to changes in environmental conditions in short timescales making their use as indicators more difficult. 


\section{Palojärvi, A. \& Nuutinen, V. Soil quality concept}

Table 4. Soil quality indicators in a sample of international and national monitoring programs.

\begin{tabular}{|c|c|c|c|c|c|c|c|c|c|}
\hline \multirow[b]{2}{*}{ Monitoring program } & \multicolumn{9}{|c|}{ Indicators of soil quality } \\
\hline & $\mathrm{pH}$ & $\begin{array}{c}\text { Organic } \\
\text { C }\end{array}$ & $\begin{array}{l}\text { Nutrient } \\
\text { status }\end{array}$ & $\begin{array}{l}\text { Heavy } \\
\text { metals }\end{array}$ & $\begin{array}{l}\text { Pesticide } \\
\text { contami- } \\
\text { nation }\end{array}$ & $\begin{array}{l}\text { Salinisa- } \\
\text { tion }\end{array}$ & $\begin{array}{l}\text { Compac- } \\
\text { tion }\end{array}$ & $\begin{array}{l}\text { Risk of } \\
\text { erosion }\end{array}$ & $\begin{array}{c}\text { "Landuse } \\
\text { missmatch" }\end{array}$ \\
\hline $\begin{array}{l}\text { International } \\
\text { OECD (OECD 2001) } \\
\text { European Environment } \\
\text { Agency (EEA 2001) } \\
\text { European Union }{ }^{1} \\
\text { (CEC 2001) }\end{array}$ & $\bullet$ & & • & $\bullet$ & $\bullet$ & & & $\begin{array}{l}\bullet \\
\bullet\end{array}$ & $\bullet$ \\
\hline $\begin{array}{l}\text { National } \\
\text { Finland }^{1} \text { (Yli-Viikari } \\
\text { et al. 2002) } \\
\text { Sweden }^{1} \text { (SEPA 1999) } \\
\text { United Kingdom } \\
\text { (MAFF 2000) } \\
\text { Canada (McRae et al. } \\
\text { 2000) }\end{array}$ & $\bullet$ & $\begin{array}{l}\bullet \\
\bullet \\
\bullet\end{array}$ & $\bullet$ & $\begin{array}{l}\bullet \\
\bullet \\
\bullet\end{array}$ & & $\bullet$ & $\bullet$ & • & \\
\hline
\end{tabular}

${ }^{1}$ A proposed set of indicators.

\section{National monitoring programmes}

National arable soil quality follow-ups take a more refined look at soil quality. In our selection of national programmes (Table 4), quality of arable soil is mainly monitored with topsoil chemical characteristics. National soil quality follow-ups often are part of broader agri-environmental monitoring systems where these variables are further used as inputs in deciphering the interaction of soils with water and air. Heavy metal content of field soils is being assessed as a factor risking animal and human health and the welfare of soil organisms. Although the importance of physical soil quality is widely acknowledged, soil physical properties are not always included in the indicator sets. Swedish (SEPA 1999) and Canadian (McRae et al. 2000) monitoring schemes include an indicator for soil compaction. The Swedish indicator is based on field measurement of soil penetrometer resistance, and the Canadian indicator on model calculations.

None of the national programmes listed here contain biological soil quality indicators in the sense that some aspect of soil life or biological- ly mediated soil process would be directly measured. Instead, soil organic matter is used as a surrogate variable for the biological activity in soil (e.g. Kirchmann and Anderson 2001). National follow-ups of biological soil quality do nevertheless exist. The Netherlands has a nationwide programme where several microbial and faunal variables are used to characterise arable soil quality (Schouten et al. 1999, referred to OECD 2001). Soil quality is assessed by comparing a given soil with a fixed reference site with desirable biological characteristics. Similar national programmes are currently being planned or implemented in other European countries: for instance, in Germany (Höper et al. 1997) and Denmark.

\section{On-farm assessment with field kits and score-cards}

A well-documented example of on-farm tools for soil quality measurement is the soil quality testing kit produced by the USDA Agricultural Research Service (USDA 1999). The kit was de- 
Vol. 11 (2002): 329-342.

veloped mainly with farmers and advisors in mind to help them understand soils and to allow relative soil quality assessment in the field. A further aim was to produce an educational tool to increase public awareness of the importance of soil quality. The kit, which is commercially available, provides for ten measurements: soil respiration, infiltration, bulk density, water content, electric conductivity (EC), $\mathrm{pH}$, soil nitrates, aggregate stability, slake test and earthworm numbers. Guidelines for the test procedures and the interpretation of results are given in a freely available booklet (USDA 1999). A recent, illustrative example of the kit's application is provided by Seybold et al. (2002).

Another approach in on-farm assessment is the use of scorecards where qualitative, mainly sensory observations of soils are scored to obtain an overall measure of soil quality or "health". An example of a soil health card is given by Romig et al. (1996). Their card aims at evaluating soil health through farmer's observations of soil, plant, animal and water properties. The soil characteristics are addressed in terms of 20 descriptive and four analytical properties, each evaluated in a three-grade scale. The descriptive properties include observations on earthworm numbers and - somewhat ill defined - general biological activity in the soil. Not all are enthusiastic about this type of qualitative and predominantly sensory evaluation of soil properties, as Sojka and Upchurch (1999) demonstrated in reservations they presented in regard to the soil quality concept.

\section{Soil quality follow-up in Finland}

\section{National monitoring}

Sustainable use of arable soils is one goal in Finland's national strategy for the use of natural resources (Maa- ja metsätalousministeriö 2001). In a set of indicators proposed for the monitoring of strategy implementation (Yli-Viikari et al.
2002), it is suggested that the national followup of arable soil quality would mainly be based on the field monitoring programme carried out by MTT Agrifood Research Finland since 1974 (e.g. Sippola and Tares 1978, Erviö et al. 1990). The programme involves measurement of topsoil chemical characteristics in a sampling network covering the whole country. The proposed set of soil quality indicators is listed in Table 4 and its justification is discussed by Yli-Viikari et al. (2002). The results from the programme's latest sampling are reported elsewhere in this issue (Mäkelä-Kurtto and Sippola 2002). According to the indicator proposal, sources of additional information for the chosen indicators will be the soil test data of Viljavuuspalvelu Oy (Viljavuuspalvelu 2000) and data from a monitoring study begun in 1992 at 150 sites at MTT farms and regional research units (Sippola et al. 2001). In the proposal it is stressed that the necessity for and possibilities to include physical and biological indicators of soil quality in the follow-up should be thoroughly investigated (Yli-Viikari et al. 2002). The need for such an investigation has been noted a number of times before (e.g. Kylä-Setälä and Assmuth 1996).

\section{Activity on field and farm level}

Soil fertility testing has a long history in Finland (see other papers in this issue). Currently there are a number of commercial laboratories that carry out the testing, typically consisting of evaluation of soil type, organic matter content, $\mathrm{pH}$, electrical conductivity, and extractable calcium $(\mathrm{Ca}), \mathrm{P}, \mathrm{K}$ and magnesium $(\mathrm{Mg})$. Thanks to intensive and regular testing and an effective farmers advisory system, the interpretation of the results is comprehensive and precise. The results are routinely used as a basis for decisions of farm level management regimes. Soil physical and biological measurements are not included in the on-farm assessments. Development of new methods for determining soil physical properties in Finnish arable soils is under way (Laura Alakukku, personal communication). 


\section{Palojärvi, A. \& Nuutinen, V. Soil quality concept}

Qualitative on-farm assessment of field soils has a strong foothold in Finland within the organic farming community where "spade diagnosis" has long been in use. Currently, an on-farm soil assessment tool based on a combination of scorecard and spade diagnosis approaches is being developed in a project headed by the Association of Rural Advisory Centres (Sari Peltonen, personal communication). One inspiration for the work is the soil structure evaluation by "spade diagnosis" developed in Germany (Beste et al. 2001). A similar type of approach has been applied in Sweden (Gustafson-Bjuréus and Karlsson 2002). The Swedish test aims at better understanding of arable soils through visual field observation of profile properties, soil structure, root development and earthworm abundance together with measurements of infiltration capacity.

\section{Future perspectives}

The evaluation of the applicability of physical and biological soil properties in soil quality assessment is an important challenge for the future. Basic research is needed in order to select and develop proper indicators, applicable at different scales. The task appears somewhat daunting in a situation where many want the information but few are willing to fund its gathering. Ingenuity is required in setting up effective study programmes, which would guarantee the accumulation of the necessary baseline data.

Tools need to be developed for integrating the information gained with the various soil quality indicators. Calculation of soil quality indexes is one method that has been suggested (e.g. Karlen et al. 2001). One problem with the application of indexes is that, in the interpretation of the results, information may sometimes be needed on the original indicator values. Furthermore, the rating of individual indicators, which is done during the index calculation, is a demanding task. Another way to proceed is to present the multi- variate data in a cobweb presentation, as is done for example in the Dutch monitoring programme of biological soil quality (above). Stenberg (1999) has suggested the use of statistical multivariate tools, such as principal components analysis, to help with the evaluation and interpretation of multiple indicators. Ecosystem level properties, such as soil resilience and resistance (Seybold et al. 1999), show promise as integrative soil quality indicators.

\section{Concluding remarks}

A clear merit of the soil quality concept and assessment is the integration of important but often separately considered aspects of soil. In the agricultural context, the integrative approach is highly useful in producing the knowledge needed by the various stakeholders of arable land management. The assessment of soil quality is invaluable in determining the sustainability of soil and land management systems and in evaluating the long-term effectiveness of the systems. Besides these positive aspects of the soil quality concept, it is worth noting that the concept is liable to justified scientific criticism regarding its conceptual foundations and premature application (Sojka and Upchurch 1999). Internationally, the implementation of the soil quality approach has improved the educational competence of the soil science community and increased the transparency of soil science to the surrounding society. Both trends are highly desirable also in Finland.

\section{Appendix}

The applicability of biological soil quality indicators: Earthworms as an example

Earthworms can be regarded as potential soil quality indicators in Finnish conditions. The local taxonomy of earthworms is well established, as are the main features of species distributions, although geographical distribution in arable soils has not been investigated (Terhivuo 1988). Earth- 
Vol. 11 (2002): 329-342.

worms are common components of arable soil communities in the main agricultural areas of Finland and their ecology in Finnish arable soils has been studied relatively intensively during the last 15 years. Here we address the indicator potential of earthworms according to the list of requirements for an efficient and applicable biological soil quality indicator given by Doran and Zeiss (2000).

Sensitivity to variation in management. The responses of earthworm communities to arable soil management have been studied extensively. It is known, for instance, that many field soil improvement practices enhance the growth of earthworm populations (e.g. Lee 1985, Edwards et al. 1995). From studies carried out in Finland, we know that earthworms are affected by the choice of tillage method (Nuutinen 1992) and rotation (Nuutinen and Haukka 1990), possibly by intense use of pesticides (Kukkonen and Vesalo 2000) and also by field drainage (Nuutinen et al. 2001). Quite often the responses are specific to particular ecological groups of earthworms. Responses to management may differ notably, however, and in unpredictable ways in different localities (Nuutinen 1992, also Bohlen et al. 1995). These differences may relate to the inherent quality of the soil (e.g. texture, $\mathrm{pH}$ ), whose significance for earthworm communities is not at all well known in Finnish soils. It is also possible that absence of a species from a given field does not depend on some aspect of soil quality but is simply due to limited dispersal. A factor that further renders it difficult to interpret field data is the apparent sensitivity of earthworm numbers to weather extremes. Together these factors imply that the definition of reference levels for earthworm numbers is difficult indeed.

Correlation with beneficial soil functions and usefulness in elucidating ecosystem processes. Earthworm activity bears on many important ecosystem services that soils provide. These include decomposition, recycling of nutrients and moderation of soil hydrology (e.g. Lee 1985, Edwards et al. 1995). In Finland, for instance, earthworms may have a significant role in the formation of macroporosity of cultivated clays (Pitkänen and Nuutinen 1997) and on the permeability of these soils (Pitkänen and Nuutinen 1998). It is thus conceivable that earthworms would be used as proxies for certain aspects of soil quality. A word of caution is nevertheless warranted. It has been pointed out that the activity of earthworms is important but not essential for many processes underlying soil quality, that good quality soils may be devoid of earthworms and that high earthworm numbers in productive soils are not necessarily the cause of high productivity (Linden et al. 1994, Gregorich et al. 1997). If high plant yield is taken as the ultimate meas- ure of good quality soil, earthworm abundance has in fact been shown to be a poor predictor of soil quality (Doube and Schmidt 1997). Further, while earthworms are predominantly beneficial in arable soils, their activities may have negative consequences, too. Examples of such cases are listed by Sojka and Upchurch (1999), while Shuster et al. (2000) and Ester and van Rozen (2002) provide two more recent examples.

Comprehensibility and usefulness to land managers. For many farmers, earthworms are a clear manifestation of good quality soil. Earthworms are easily observed, and, unlike many other soil organisms, they are familiar to all those who deal with arable land. This evidently has rendered earthworms an appealing indicator in practical on-farm assessment of soil properties.

Ease and expenditure of measurement. Methods for the measurement of earthworm abundance are well defined and simple (Baker and Lee 1993, ISO 11268-3). Although labour intensive, the methods are cheaper than many other soil measurements. The skills needed in sampling and treatment of the material, even to the level of identification of ecological groups or species of earthworms, can also be obtained relatively quickly. Experience and care are needed in planning the temporal and spatial aspects of field sampling.

Bearing in mind the reservations noted above, we propose that earthworms have good potential to serve as biological indicators of arable soil quality. It is particularly useful to include earthworms in studies aimed at understanding the processes underlying soil quality. We also believe that the incorporation of earthworm observations is useful in on-farm assessment of soils. However, owing to the lack of a reference system, only relative assessment is possible, either by comparing different managements in similar conditions or by following the temporal changes in earthworm numbers under given management.

Although earthworms are already relatively well-studied organisms in Finnish arable soils, better knowledge of the significance of inherent soil quality for their numbers and information on the geographical distribution patterns in arable soils would be highly useful. It has recently been recommended that a survey where such baseline data is collected would be initiated in Finland (Ministry of the Environment 2001).

Acknowledgements. We thank Kathleen W. Ahonen for English language revision. 


\author{
Palojärvi, A. \& Nuutinen, V. Soil quality concept
}

\title{
References
}

Arshad, M.A. \& Martin, S. 2002. Identifying critical limits for soil quality indicators in agro-ecosystems. Agriculture, Ecosystems and Environment 88: 153-160.

Baker, G.H. \& Lee, K.E. 1993. Earthwoms. In: Carter, M.R. (ed.). Soil sampling and methods of analysis. Boca Raton: Lewis Publishers. p. 359-371.

Bengtsson, J. 1998. Which species? What kind of diversity? Which ecosystem function? Some problems in studies of relations between biodiversity and ecosystem function. Applied Soil Ecology 10: 191-199.

Beste, A., Hampl, U. \& Kustel, N. 2001. Bodenschutz in der Landwirtschaft. Einfache Bodenbeurteilung für Praxis, Beratung und Forschung. Ökölogische Konzepte 101. SÖL. Bad Duerkheim. 111 p.

Blair, J.M., Bohlen, P.J. \& Freckman, D.W. 1996. Soil invertebrates as indicators of soil quality. In: Doran, J.W. \& Jones, A.J. (eds.). Methods for assessing soil quality. SSSA Special Publication No. 49. Madison, Wisconsin: Soil Science Society of America, Inc. p. 273-291.

Blum, W.E.H. \& Santelises, A.A. 1994. A concept of sustainability and resilience based on soil functions. In: Greenland, D.J. \& Szabolcs, I. (eds.). Soil resilience and sustainable land use. Wallingford, UK: CAB International. p. 535-542.

Bohlen, P.J., Edwards, W.M. \& Edwards, C.A. 1995. Earthworm community structure and diversity in experimental agricultural watersheds in Northeastern Ohio. Plant and Soil 170: 233-239.

CEC 2001. Statistical information needed for indicators to monitor the integration of environmental concerns into common agricultural policy. Communication from the commission of the council and the European parliament. Brussels: Commission of the European Communities. $21 \mathrm{p}$.

Doran, J.W. \& Parkin, T.B. 1994. Defining and assessing soil quality. In: Doran. J.W. et al. (eds.). Defining soil quality for sustainable environment. SSSA Special Publication No. 35. Madison, Wisconsin: Soil Science Society of America, Inc. and American Society of Agronomy, Inc. p. 3-21.

Doran, J.W. \& Safley, M. 1997. Defining and assessing soil health and sustainable productivity. In: Pankhurst, C. et al. (eds.). Biological indicators of soil health. Wallingford, UK: CAB International. p. 1-28.

Doran, J.W., Sarrantonio, M. \& Liebig, M. 1996. Soil health and sustainability. In: Sparks, D.L. (ed.). Advances in Agronomy, Vol 56. New York: Academic Press. P. 1-54.

Doran, J.W. \& Zeiss, M.R. 2000. Soil health and sustainability: managing the biotic component of soil quality. Applied Soil Ecology 15: 3-11.

Doube, B.M. \& Schmidt, O. 1997. Can the abundance or activity of soil macrofauna be used to indicate the biological health of soils? In: Pankhurst, C. et al. (eds.). Biological indicators of soil health. Wallingford, UK: CAB International. p. 265-295.

Edwards, C.A., Bohlen, P.J., Linden, D.R. \& Subler, S.
1995. Earthworms in agroecosystems. In: Hendrix, P.F. (ed.). Earthworm ecology and biogeography in North America. Boca Raton: Lewis Publishers. p. 185-213.

EEA 2001. Proposal for a European soil monitoring and assessment framework. European Environment Agency. Technical report $61.58 \mathrm{p}$.

Erviö, R., Mäkelä-Kurtto, R. \& Sippola, J. 1990. Chemical characteristics of Finnish agricultural soils in 1974 and in 1987. In: Kauppi, P. et al. (eds.). Acidification in Finland: Finnish acidification research programme HAPRO 1985-1990. Berlin: Springer Verlag. p. 217234.

Ester, A. \& van Rozen, K. 2002. Earthworms (Aporrectodea spp.; Lumbricidae) cause soil structure problems in young Dutch polders. European Journal of Soil Biology 38: 181-185.

Gregorich, E.G., Carter, M.R., Doran, J.W., Pankhurst, C.E. \& Dwyer, L.M. 1997. Biological attributes of soil quality. In: Gregorich, E.G. \& Carter, M.R. (eds.). Soil quality for crop production and ecosystem health. Developments in Soil Science 25. Amsterdam: Elsevier. p. 81-113.

Gustafson-Bjuréus, A. \& Karlsson, J. 2002. Markstrukturindex - utvärdering av en metod att bedöma odlingsystemets uthållighet och jordarnas fysikaliska status. Swedish University of Agricultural Science, Department of Soil Sciences, Division of Agricultural Hydrotechnics. Communications 02:2. Uppsala. $167 \mathrm{p}$.

Harris, R.F. \& Bezdicek, D.F. 1994. Descriptive aspects of soil quality/health. In: Doran, J.W. et al. (eds.). Defining soil quality for a sustainable environment. SSSA Special Publication No. 35. Madison, Wisconsin: Soil Science Society of America, Inc. and American Society of Agronomy, Inc. p. 23-35.

Hendrix, P.F., Crossley D.A., Jr., Blair, J.M. \& Coleman, D.C. 1990. Soil biota as components of sustainable agroecosystems. In: Edwards, C.A. et al. (eds.). Sustainable agricultural systems. Ankeny, lowa: Soil and Water Conservation Society. p. 637-654.

Höper, H., Heinemeyer, O. \& Kleefisch, B. 1997. Erfassung bodenmikrobiologischer Parameter im Rahmen der Bodendauerbeobachtung in Niedersachen. Mitteilungen der Deutschen Bodenkundlichen Gesellschaft 85: 913-916.

ISO 11268-3. Soil quality - Effects of pollutants on earthworms - Part 3: Guidance on the determination of effects in field situations. International organization for standardization, 1999. 8 p.

Karlen, D.L., Andrews, S.S. \& Doran, J.W. 2001. Soil quality: current concepts and applications. In: Sparks, D.L. (ed.). Advances in Agronomy, Vol 74. San Diego, California: Academic Press. p. 1-40.

Karlen, D.L., Mausbach, M.J., Doran, J.W., Cline, R.G., Harris, R.F. \& Schuman, G.E. 1997. Soil quality: a concept, definition, and framework for evaluation. Soil Science Society of America Journal 61: 4-10. 
Vol. 11 (2002): 329-342.

Kirchmann, H. \& Andersson, R. 2001. The Swedish system for quality assessment of agricultural soils. Environmental Monitoring and Assessment 72: 129139.

Kukkonen, S. \& Vesalo, S. 2000. Indication of soil degradation in strawberry fields: disappearance of earthworms. In: Elmholt, S. et al. (eds.). Soil stresses, quality and care. Proceedings from NJF seminar 310. DIAS Report Plant Production 38: 99-108.

Kylä-Setälä, A. \& Assmuth, T. 1996. Suomen maaperän tila, kuormitus ja suojelu. Summary: Condition, loading and protection of soil in Finland. The Finnish Environment 10. Helsinki: Edita. 156 p. (in Finnish with English summary).

Ladd, J.N., Foster, R.C., Nannipieri, P. \& Oades, J.M. 1996. Soil structure and biological activity. In: Stotzky, G. \& Bollag, J.-M. (eds.). Soil Biochemistry, Vol. 9. New York: Marcel Dekker Inc. p. 23-78.

Larson, W.E. \& Pierce, F.J. 1994. The dynamics of soil quality as a measure of sustainable management. In: Doran, J.W. et al. (eds.). Defining soil quality for sustainable environment. SSSA Special Publication No. 35. Madison, Wisconsin: Soil Science Society of America, Inc. and American Society of Agronomy, Inc. p. 37-51.

Lavelle, P. 1997. Faunal activities and soil processes: adaptive strategies that determine ecosystem function. Advances in Ecological Research 27: 93-132.

Lee, K.E. 1985. Earthworms. Their ecology and relationships with soils and land use. Sydney: Academic Press. $411 \mathrm{p}$.

Linden, D.R., Hendrix, P.F., Coleman, D.C. \& van Vliet, P.C.J. 1994. Faunal indicators of soil quality. In: Doran, J.W. et al. (eds.). Defining soil quality for sustainable environment. SSSA Special Publication No. 35. Madison, Wisconsin: Soil Science Society of America, Inc. and American Society of Agronomy, Inc. p. 91-106.

Maa- ja metsätalousministeriö 2001. Maa- ja metsätalousministeriön luonnonvarastrategia. Uusiutuvien luonnonvarojen kestävä käyttö. MMM:n julkaisuja 8/ 2001. $112 \mathrm{p}$.

McRae, T., Smith, C.A.S. \& Gregorich, L.J. (eds.). 2000. Environmental sustainability of Canadian agriculture: Report of the agri-environmental indicator project. A summary. Ottawa, Ontario: Agriculture and Agri-Food Canada. $19 \mathrm{p}$.

MAFF 2000. Towards sustainable agriculture: $A$ pilot set of indicators. London: Ministry of Agriculture, Forestry and Fishery. $72 \mathrm{p}$.

Mäkelä-Kurtto, R. \& Sippola, J. 2002. Monitoring Finnish arable land: changes in soil quality 1987-1998. Agricultural and Food Science in Finland 11:273-284.

Ministry of the Environment 2001. Proposal for a national monitoring system of biological diversity. The Finnish Environment 532. Helsinki: Edita. 76 p. (in Finnish with English summary).

Nortcliff, S. 2002. Standardisation of soil quality attributes. Agriculture, Ecosystems and Environment 88: 161168.

Nuutinen, V. 1992. Earthworm community response to tillage and residue management on different soil types in southern Finland. Soil \& Tillage Research 23: 221-239.

Nuutinen, V. \& Haukka, J. 1990. Conventional and organic cropping systems at Suitia VII: Earthworms. Journal of Agricultural Science in Finland 62: 357367.

Nuutinen, V., Pöyhönen, S., Ketoja, E. \& Pitkänen, J. 2001. Abundance of the earthworm Lumbricus terrestris $\mathrm{L}$. in relation to subsurface drainage pattern on a sandy clay field. European Journal of Soil Biology 37: 301-304.

OECD 2001. Environmental indicators for agriculture. Volume 3. Methods and results. Paris: OECD, Agriculture and Food. 409 p.

Oldeman, L.R. 1994. The global extent of soil degradation. In: Greenland, D.J. \& Szabolcs, I. (eds.). Soil resilience and sustainable land use. Wallingford, UK: CAB International. p. 99-118.

Palojärvi, A., Alakukku, L., Martikainen, E., Niemi, M., Vanhala, P., Jørgensen, K. \& Esala, M. 2002. Luonnonmukaisen ja tavanomaisen viljelyn vaikutukset maaperään. Abstract: Effects of organic and conventional farming on soil. Agrifood Research Report 2. 88 p. (in Finnish with English abstract).

Patzel, N., Sticher, H. \& Karlen, D.L. 2000. Soil fertility phenomenon and concept. Journal of Plant Nutrition and Soil Science 163: 129-142.

Pitkänen, J. \& Nuutinen, V. 1997. The distribution and abundance of burrows made by Lumbricus terrestris and Aporrectodea caliginosa in the soil profile. Soil Biology and Biochemistry 29: 463-467.

Pitkänen, J. \& Nuutinen, V. 1998. Earthworm contribution to infiltration and surface runoff after 15 years of different soil management. Applied Soil Ecology 9: 411-415.

Romig, D.E., Garlynd, M.J. \& Harris, R.F. 1996. Farmerbased assessment of soil quality: a soil health scorecard. In: Doran, J.W. \& Jones, A.J. (eds.). Methods for assessing soil quality. SSSA Special Publication No. 49. Madison, Wisconsin: Soil Science Society of America, Inc. p. 39-60.

Sarrantonio, M., Doran, J.W., Liebig, M.A. \& Halvorson, J.J. 1996. On-farm assessment of soil quality and health. In: Doran, J.W. \& Jones, A.J. (eds.). Methods for assessing soil quality. SSSA Special Publication No. 49. Madison, Wisconsin: Soil Science Society of America, Inc. p. 83-105.

Schouten, A.J., Breure, A.M., Bloem, J., Didden, W., de Ruiter, P.C. \& Siepel, H. 1999. Life support functies van de bodem: operationalisering t.b.v. het biodiversiteitsbeleid. Summary: Life support functions of the soil: Operationalisation for biodiversity policy. RIVM Report 607601003. Bilthoven: the Netherlands Institute of Public Health and Environment. 55 p. (in Dutch with English summary).

SEPA 1999. Bedömningsgrunder för miljökvalitet. Odlingslandskapet. Swedish Environmental Protection Agency. Report 4916. Uppsala: Naturvårdsverket Förlag. 80 p.

Seybold, C.A., Herrick, J.E. \& Brejda, J.J. 1999. Soil resilience: a fundamental component of soil quality. Soil Science 164: 224-234. 


\title{
Palojärvi, A. \& Nuutinen, V. Soil quality concept
}

Seybold, C.A., Hubbs, M.D. \& Tyler, D.D. 2002. On-farm tests indicate effects of long-term tillage systems on soil quality. Journal of Sustainable Agriculture 19: 6173.

Shuster, W.D., Subler, S. \& McCoy, E.L. 2000. Foraging by deep-burrowing earthworms degrades surface soil structure of a fluvenic Hapludoll in Ohio. Soil \& Tillage Research 54: 179-189.

Sippola, J., Kivistö, P. \& Mäkelä-Kurtto, R. 2001. Tutkimusasemien viljelymaiden ravinne- ja raskasmetallipitoisuuksien seuranta. Muutokset aikavälillä 19921997. MTT:n julkaisuja, Sarja B. $13 p+6$ appendixes.

Sippola, J. \& Tares, T. 1978. The soluble content of mineral elements in cultivated Finnish soils. Acta Agriculturae Scandinavica, Suppl. 20: 11-25.

Sojka, R.E. \& Upchurch, D.R. 1999. Reservations regarding the soil quality concept. Soil Science Society of America Journal 63: 1039-1054.

Stenberg, B. 1999. Monitoring soil quality of arable land: Microbiological indicators. Review article. Acta Agriculturæ Scandinavica Section B, Soil and Plant Science 49: 1-24.

Swift, M.J., Heal, O.W. \& Anderson, J.M. 1979. Decomposition in terrestrial ecosystems. Berkeley and Los Angeles: University of California Press. 372 p.
Terhivuo, J. 1988. Finnish Lumbricidae (Oligochaeta) fauna and its formation. Annales Zoologici Fennici 25: 229-247.

USDA 1999. Soil quality test kit guide. United States Department of Agriculture, Agricultural Research Service and Natural Resources Conservation Centre. Available at: http://soils.usda.gov/sqi/kit2.html. Updated October 2002. Cited 25.10.2002.

Valpasvuo-Jaatinen, P., Rekolainen, S. \& Latostenmaa, H. 1997. Finnish agriculture and its sustainability: environmental impacts. Ambio 26: 448-455.

Vestberg, M., Kukkonen, S., Saari, K., Uosukainen, M., Palojärvi, A., Tuovinen, T., Vepsäläinen, M. \& Niemi, M. 2002. Cropping system impact on soil quality determinants. Agricultural and Food Science in Finland 11: 311-328.

Viljavuuspalvelu 2000. Viljavuustutkimuksen tulkinta peltoviljelyssä. Viljavuuspalvelu. $31 \mathrm{p}$.

Yli-Viikari, A., Risku-Norja, H., Nuutinen, V., Heinonen, E., Hietala-Koivu, R., Huusela-Veistola, E., Hyvönen, T., Kantanen, J., Raussi, S., Rikkonen, P., Seppälä, A. \& Vehmasto, E. 2002. Agri-environmental and rural development indicators - A proposal. Agrifood Research Report 5. 102 p. +3 appendixes.

\section{SELOSTUS}

\section{Maan laadun käsite suomalaisen maatalousmaan tutkimuksessa}

\author{
Ansa Palojärvi ja Visa Nuutinen \\ MTT (Maa- ja elintarviketalouden tutkimuskeskus)
}

Maatalousmaa on toiminnallinen kokonaisuus, ja sen tila on keskeinen sadontuotolle. Maaperän toiminta on merkittävää myös koko ekosysteemille, koska maaperällä on tärkeä rooli globaaleissa ravinnekierroissa ja -virroissa. Englanninkielisessä kirjallisuudessa on nostettu esiin maan laadun (soil quality) käsite. Se yhdistää maaperän kemialliset, fysikaaliset ja biologiset ominaisuudet, sekä ottaa huomioon maaperän vuorovaikutuksen vesistöjen ja ilmakehän kanssa. Maan laadun käsitteessä on myös maatalouskäytäntöjen ja maankäyttömuotojen kestävyyden arvioinnin näkökulma. Tässä artikkelissa tarkastellaan maan laadun käsitettä ja sen sovellutuksia, sekä arvioidaan käsitteen merkitystä suomalaisen maatalousmaan tutkimuksessa.

Viljelymaan viljavuustutkimus on organisoitu ja toteutettu Suomessa hyvin, ja kuva suomalaisen maatalousmaan kemiallisten ominaisuuksien vaihtelusta on kattava. Sen sijaan maaperän fysikaalisten ja erityisesti biologisten ominaisuuksien tietämys on puutteellista, vaikka ne on enenevässä määrin todettu tärkeiksi maan laadulle. Maaperän laadun seurantaan eri tarkoituksiin ja eri mittakaavoissa (lohko, alue, kansallinen, kansainvälinen) tarvitaan sopivat mittarit. Tässä artikkelissa keskitytään tiettyjen biologisten mittareiden mahdolliseen merkitykseen ja käyttökelpoisuuteen. Perustutkimusta tarvitaan nykyistä enemmän, jotta tutkijoilla ja neuvojilla olisi vankka perusta luotettavan tiedon välittämiseen maan laadusta. Maan laadun käsitettä on myös arvosteltu oikeutetusti. Käsitteen selkeitä ansioita ovat kuitenkin maaperän kokonaisvaltainen tarkastelu ja ympäristönäkökulman painottaminen. 